\title{
نواتج أيض نشطة بيولوجيا من مرجان البحر الاحمر سينيولاريا بوليداكتيلا محمد علي غندورة
}

قسم الكيمياء البحرية ، كلية علوم البحار ، جامعة الملك عبدالعزيز علورو

جده ، المملكة العربية السعودية

المستخلص: تم عزل و تعريف مركب تربين ثنائى، ساركتروكيلدايول (1) و كنلك مركب سيسكوتربين

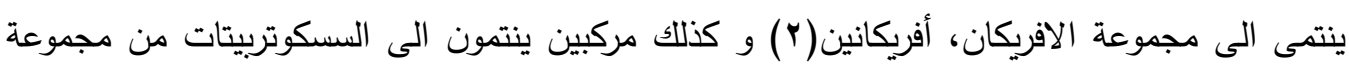
الارومادندرين، •1 (ع ()-ارومادندرين (ץ) و البالوسترول (£) من مرجان البحر الاحمر الرخو

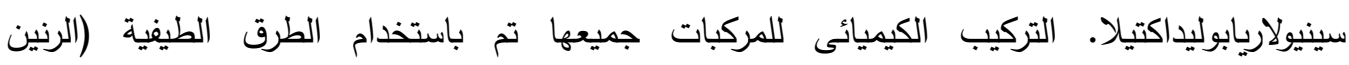
النووبالمغناطيسى، مطياف الكتلة، طيف الاشعة تحت الحمراء وطيف الاشعة فوق البنفجية). تم تعيين نثاط هذه المركبات كمضادات لبعض انواع من البكتيريا. 
The data obtained from Table 2 shows that 1 exhibits potent activity against $B$. subtilis and $P$. aeruginosa. While the $\mathbf{1}, \mathbf{2}$ and 4 show potent activity against $B$. subtilis.

Table 2. Diameter of inhibition zone in $\mathrm{mm}$ at concentration level of $1 \mathrm{mg} / \mathrm{ml}$ and Minimum inhibitory concentration (MIC) in $\mathbf{m g} / \mathbf{m l}$

\begin{tabular}{|ccc|}
\hline Compound & $\begin{array}{c}\text { B. subtilis } \\
\text { MIC }(\mathrm{mg} / \mathrm{ml})\end{array}$ & $\begin{array}{c}\text { P. aeruginosa } \\
\text { MIC }(\mathrm{mg} / \mathrm{ml})\end{array}$ \\
\hline $\mathbf{1}$ & 17.9 & 18.2 \\
& 0.4 & 0.2 \\
$\mathbf{2}$ & 12.7 & 9.8 \\
& 0.6 & - \\
$\mathbf{3}$ & 17.9 & 10.0 \\
& 0.3 & - \\
$\mathbf{4}$ & 17.6 & 11.1 \\
& 0.5 & - \\
\hline
\end{tabular}

\section{Acknowledgement}

The author thanks the marine biologist Mr. Kamal Al-Dahoudy, Faculty of Maritime, King Abdulaziz University for collection and identification of the sample.

\section{References}

Abdel-Lateff, A., Alarif, W.M., Ayyad, S-E.N., Al-Lihaibi, S.S. and Basaif, S.A. (2014) Newcytotoxic isoprenoid derivatives from the red sea soft coral Sarcophyton glaucum. Natural product Research,29: 24-30.

Al-Lihaibi, S.S., Alarif, W.M. , Abdel-Lateef, A., Ayyad, SE. N., Abdel-Naim, A.B., El-Senduny, F.E. and Badria, F.A. (2014) Three new cembranoid-type diterpenes from Red Sea soft coral Sarcophyton glaucum: isolation and Antiproliferative activity against HepG2 cells, European Journal Medicinal Chemistry, 81: 314-322.

Barnes, R.D. (1968) Invertebrate zoology (2nd ed., pp. 101113). Philadelphia: Saunders.

Blunt, J.W., Brent, C.R., Munro, H.G., Peter, T. N. and Michele, R.P.(2003) Marine natural products. Natural Product Reports, 20: 1-48.

Cheer, C.J., Smith, D.H., Djerassi, C., Tursch, B., Braekman, I. C. and Daloze, D. (1976) Applications of artificial intelligence for chemical inference-XXI: Chemical studies of marine invertebrates-XVII. The computer-assisted identification of [+]-palustrol in the marine organism Cespitularia sp., aff.subviridis. Tetrahedron, 32: 1807-1810.

Chen, W-T., Liu, H-L., Yao, L-G. and Guo, Y-w. (2015) 9,11-Secosteroids and polyhydroxylated steroids from two South China Sea soft corals Sarcophyton trocheliophorum and Sinularia flexibilis. Steroids, 92: 56-61.

Gruickshank, R., Duguid, J. R., Marmion, B. P. and Swain, R. H. A. (1975) Medicinal Microbiology", Vol. 11. Churchill Livingstone, New York, p. 190.

Kashman, Y., Bodner, M., Finer-Moore, J. S. and Clardy, J. (1980) $\Delta^{9(15)}$-africanenea new sesquiterpene hydrocarbon from the soft coral Sinularia erecta. Experientia, 36: 891-892.

Lakshmi, V. and Kumar, R. (2009) Metabolites from Sinularia species.Natural Product Research, 23, 801850.

Lei, L-F., Chen, M-F., Wang, T., He, X-X., Liu, B-X., Deng, Y., Chen, X-J., Li, Y-T., Guan,S-Y., Yao, JH., Li, W., Ye, W-C., Zhang, D-M.and Zhang, CX. (2014) Novel cytotoxic nine-membered macrocyclic polysulfur cembranoid lactones from the soft coral Sinularia sp., Tetrahedron, 70: 6851-6858.

Reddy, G.B.S., Rao, D.V., Rao, C.B., Dhananjaya, N., Kuttan, R., and Babu, T.D.(1999)Isolation and structural determination of new sphingolipids and pharmacological activity of africanene and other metabolites from Sinularia leptoclados. Chemical \& Pharmaceutical Bulletin, 47: 1214-1220.

Scheuer. P.J. (1987) Marine Natural Products, Chemical and Biological Perspective. Terpenoids from Coelenterates, Academic Press, New York, pp 247 296.

Warmers, U. and König, W.A. (1999) Sesquiterpene constituents of the liverwort Calypogeia fissa. Phytochemistry, 52:695-704.

Zubair, M. S., Alarif, W. M., Al-Footy, Kh. O., Mohamed PH, Aly, M. M., Basaif, S. A., Al-Lihaibi, S. S. and Ayyad, S-E. N. (2016) New antimicrobial biscembrane hydrocarbon and cembranoid diterpenes from the soft coral Sarcophyton trocheliophorum, Turkish Journal of Chemistry, 40 (3): 385-392. 
Table $1 .{ }^{1} \mathrm{H}$ - and ${ }^{13} \mathrm{C}$-NMR (at 600 and $150 \mathrm{MHz}$, resp., in $\mathrm{CDCl}_{3}$ ) spectral data ${ }^{\mathrm{a}}$ of 1 and 2 . Atom numbering as indicated in Fig.1

\begin{tabular}{|c|c|c|c|c|}
\hline & \multicolumn{2}{|r|}{1} & \multicolumn{2}{|r|}{2} \\
\hline & $\delta(C)$ & $\delta(\mathbf{H}), J \mathbf{H z}$ & $\delta(C)$ & $\delta(\mathbf{H}) J \mathbf{H z}$ \\
\hline 1 & $45.6(d)$ & $1.34-1.36(\mathrm{~m})$ & $52.7(d)$ & $1.32(\mathrm{~m})$ \\
\hline 2 & $72.0(d)$ & $4.62(d d, 10.8 ; 4.8)$ & $18.8(s)$ & - \\
\hline \multirow[t]{2}{*}{3} & $124.4(d)$ & $5.28(d, 10.8)$ & $23.3(t)$ & $0.54(d d d, 12.0,8.4,3.6)$ \\
\hline & & & & $0.19(\mathrm{t}, 4.2)$ \\
\hline 4 & $141.2(s)$ & - & $22.0(d)$ & $0.49(m)$ \\
\hline \multirow[t]{2}{*}{5} & $42.5(t)$ & $2.75-2.80\left(d d, 12.0,10.8 \mathrm{H}_{\mathrm{a}}\right)$ & $43.2(t)$ & $1.81(\mathrm{~m})$ \\
\hline & & $2.54-2.57\left(d d, 12.0,4.2 \mathrm{H}_{\mathrm{b}}\right)$ & & $1.11(m)$ \\
\hline 6 & $128.2(d)$ & 5.84-5.89 (dddd, 15.6, 10.8, 4.2) & $33.6(s)$ & - \\
\hline \multirow[t]{2}{*}{7} & $135.7(d)$ & $5.41(\mathrm{brd}, 15.6)$ & $51.2(t)$ & $1.73(\mathrm{~m})$ \\
\hline & & & & $1.08(\mathrm{~m})$ \\
\hline 8 & $73.6(s)$ & - & $42.2(d)$ & $2,43(\mathrm{ddd}, 9,6,2.4)$ \\
\hline 9 & $39.9(t)$ & $1.54-1.56\left(m, \mathrm{H}_{\mathrm{a}}\right), 1.86-1.88\left(m, \mathrm{H}_{\mathrm{b}}\right)$ & $158.3(s)$ & - \\
\hline \multirow[t]{2}{*}{10} & $22.8(t)$ & $1.74-1.76\left(m, \mathrm{H}_{\mathrm{a}}\right), 1.26-1.30\left(m, \mathrm{H}_{\mathrm{b}}\right)$ & $33.6(t)$ & $2.41(\mathrm{ddd}, 8.4,7.2,1.2)$ \\
\hline & & & & $2.25(m)$ \\
\hline \multirow[t]{2}{*}{11} & $75.8 .6(d)$ & $3.48(d, 9.6)$ & $27.7(t)$ & $1.70(\mathrm{~m})$ \\
\hline & & & & $1.57(m)$ \\
\hline 12 & $74.9(\mathrm{~s})$ & - & $24.1(q)$ & $1.05(\mathrm{~s})$ \\
\hline 13 & $18.6(t)$ & $1.62-1.64\left(m, \mathrm{H}_{\mathrm{a}}\right), 1.35-1.36\left(m, \mathrm{H}_{\mathrm{b}}\right)$ & $20.5(q)$ & $0.98(\mathrm{~s})$ \\
\hline 14 & $34.1(t)$ & $2.28-2.32\left(m, \mathrm{H}_{\mathrm{a}}\right), 1.20-1.22\left(m, \mathrm{H}_{\mathrm{b}}\right)$ & $33.9(d)$ & $0.90(s)$ \\
\hline 15 & $29.4(d)$ & $1.20-1.22(m)$ & $106.3(t)$ & $4.86(\mathrm{q}, 1.2)-4.72(s)$ \\
\hline 16 & $20.7(q)$ & $0.88(d, 6.6)$ & & \\
\hline 17 & $20.5(q)$ & $0.76(d, 6.6)$ & & \\
\hline 18 & $17.6(q)$ & $1.83(s)$ & & \\
\hline 19 & $29.3(q)$ & $1.33(s)$ & & \\
\hline 20 & $23.8(q)$ & $1.04(s)$ & & \\
\hline
\end{tabular}

${ }^{\mathrm{a}}$ All assignments are based on 1D and 2D recordings (HMBC, HSQC, COSY)

Compounds $\Delta^{9(15)}$-africanene (2), 10(14)- 1975 ) against Gram-positive (Bacillus subtilis) aromadendrene (3) and palustrol (4), were and Gram-negative bacteria (Pseudomonas. identified by comparison of their spectral data aeruginosa), at $1 \mathrm{mg} / \mathrm{ml} \mathrm{concentration.} \mathrm{The}$ with those in the literature (Kashman et al., 1980; Warmers and König, 1999; Cheer et al., 1976).

Biological activity of the compounds 1-4, were screened for their antibacterial activity by disk-diffusion technique (Gruickshank et al., inhibited zone diameters were measured and recorded in Table 2. Furacin was used as a standard compound. The minimal inhibitory concentration (MIC) of the strongly active compounds were also measured and listed in Table 2. 
$18.7\left(\mathrm{CH}_{3}, \mathrm{C}-14\right), 17.7\left(\mathrm{CH}_{3}, \mathrm{C}-15\right), 15.6$ $\left(\mathrm{CH}_{3}, \mathrm{C}-12\right)$.

\section{Results and Discussion}

The $\mathrm{CH}_{2} \mathrm{Cl}_{2}$-soluble material of the $\mathrm{CHCl}_{3}: \mathrm{MeOH}$ extract of the soft bodied organism Sinularia polydactyla was subjected to successive column and PTLC chromatographic purification processes to obtain 1 (3.5 mg, 0.0044\%), 2 (3.6 mg, $0.0046 \%), 3(2.8 \mathrm{mg}, 0.0035 \%)$ and $4(5.5 \mathrm{mg}$, $0.0069 \%)$.

Compound 1 was obtained as gummy material. 1 was analysed for $\mathrm{C}_{20} \mathrm{H}_{34} \mathrm{O}_{3}$ on the basis of HREIMS at $\mathrm{m} / z 322.2500(\mathrm{M})^{+}$and ${ }^{13} \mathrm{C}$ NMR spectra, implying four degrees of unsaturation. The ${ }^{13} \mathrm{C}$ ( $c f$. exp.) and DEPT NMR experiments allowed the determination of 20 resonances attributable to five $\mathrm{Me}$ carbons $\left(\delta_{\mathrm{C}} 17.6,20.5,20.7,23.8\right.$, and 29.3), five $\mathrm{sp}^{3} \mathrm{CH}_{2}$ carbons $(42.5,39.9,22.8,34.1$, and 18.6), four $\mathrm{sp}^{3} \mathrm{CH}$ carbons including two oxygen-bearing (72.0, and 75.8), three $\mathrm{sp}^{2} \mathrm{CH}$ $(124.4,128.2$, and 135.7) and three quaternary $\mathrm{C}$-atoms including two O-bearing (73.6 and 74.9). The ${ }^{1} \mathrm{H}$ NMR and COSY NMR of 1 displayed three Me singlet signals $\left(\delta_{\mathrm{H}} 1.83\right.$, $1.33,1.04)$, one ${ }^{i} \operatorname{Pr}\left[\delta_{\mathrm{H}} 1.22(\mathrm{~m}, 1 \mathrm{H}), 0.88(\mathrm{~d}, J\right.$ $=6.6 \mathrm{~Hz}, 3 \mathrm{H})$ and $0.76(\mathrm{~d}, J=6.6 \mathrm{~Hz}, 3 \mathrm{H})]$, three olefinic protons $\left[\delta_{\mathrm{H}} 5.28(\mathrm{~d}, J=10.8\right.$ $\mathrm{Hz}$ ), 5.85 (ddd, $J=15.6,10.8,4.2 \mathrm{~Hz}$ ) and 5.41 (br d, $J=15.6 \mathrm{~Hz}$ )] and two O-bearing $\mathrm{CH}$ protons $\left[\delta_{\mathrm{H}} 4.62(\mathrm{dd}, J=10.8,4.8 \mathrm{~Hz}), 3.48(\mathrm{~d}\right.$, $J=9.6 \mathrm{~Hz}$ )]. The NMR data of $\mathbf{1}$ displayed great similarity to those of known sarcotrocheliol (5) (Al-Lihaibi et al., 2014).

The main difference were signals at $\delta_{\mathrm{C}}$ 128.2 and 135.7 , suggesting the presence of a disubstituted double bond system in 1, instead of a trisubstituted double bond system in $\mathbf{5}$, and a signal at 73.6, indicating an extra oxygenated quaternary carbon. The ${ }^{13} \mathrm{C}$ NMR signals at $\delta_{\mathrm{C}} 124.4$ and 141.2 indicated a nonconjugated trisubstituted double bond belongs to $\mathrm{C}-3-\mathrm{C}-4$ based on the HMBC correlation with Me-18, also ${ }^{13} \mathrm{C}$ NMR signals at $\delta_{\mathrm{C}} 128.2$ and 135.7 were assigned as non-conjugated disubstituted double bonds belongs to C-6-C-7 by $\mathrm{HMBC}$ correlation between Me-19 and C7. Moreover, ${ }^{1} \mathrm{H}-{ }^{1} \mathrm{H}$ COSY spectral analysis established three partial structures of consecutive proton spin systems from $\mathrm{H}-5$ to $\mathrm{H}-7$ through $\mathrm{H}-6$; from $\mathrm{H}-9$ to $\mathrm{H}-11$ through $\mathrm{H}-10$, and finally from $\mathrm{H}-3$ to $\mathrm{H}-13$ through $\mathrm{H}-$ 2, H-1 (H-15), H-14 and H-13. These data, together with the HMBC correlations, from $\mathrm{H}$ 16 to $\mathrm{C}-15, \mathrm{C}-17$, and $\mathrm{C}-1$; from $\mathrm{H}-18$ to $\mathrm{C}-3$, C-4, and C-5; from H-19 to C-7, C-8, and C-9 and from $\mathrm{H}-20$ to $\mathrm{C}-12, \mathrm{C}-11$ and $\mathrm{C}-13$ have established the connectivity within the 14membered ring (Figure 2).

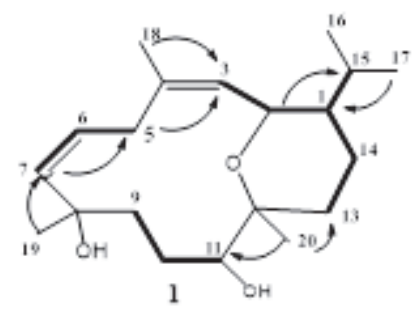

Figure 2. Selected ${ }^{1} \mathrm{H}-{ }^{1} \mathrm{H}$ COSY (- $)$ and HMB $(\mathrm{H} \rightarrow \mathrm{C})$ correlation of compound 1

Analysis of all the NMR spectroscopic data confirmed $\mathbf{1}$ to be a cembranoid derivative, $\mathbf{1}$ was previously isolated by Zubair et al. 2016 but from the genus sarcophyton and given the name sarcotrocheldiol A 
and further purified by preparative TLC of glass supported silica gel plates $(20 \mathrm{~cm}$ x 20 $\mathrm{cm})$ of $250 \mu \mathrm{m}$ thickness.

The fraction A eluted with 100\% $n$-hexane $(19: 1,23.00 \mathrm{mg})$ was purified by preparative TLC using solvent system (100\%) $n$-hexane. The band with $\mathrm{R}_{\mathrm{f}} 0.95$ (violet color with sulfuric acid - methanol) was taken to give compound 3 as colorless oil (3.5 mg). The fraction $\mathrm{B}$ eluted with $n$-hexane:ethyl acetate $(19: 1,15.00 \mathrm{mg})$ was purified by preparative TLC using the solvent system $n$-hexane:ethyl acetate $(19: 1)$, the band with $\mathrm{R}_{\mathrm{f}}=0.68$ (orange-brown color with sulfuric acidmethanol) was taken to give colorless oil (3.6 $\mathrm{mg}$ ) compound (2). The fraction $\mathrm{C}$ eluted with $n$-hexane:ethyl acetate $(4: 1,30.00 \mathrm{mg})$ was purified by preparative TLC using the solvent system $n$-hexan:ethyl acetate (7:3). The band with $\mathrm{R}_{\mathrm{f}}=0.56$ (violet color with sulfuric acidmethanol) was taken to give colorless oil (5.50 $\mathrm{mg}$ ) of compound 4.

The fraction $\mathrm{D}$ eluted with $\mathrm{CH}_{2} \mathrm{Cl}_{2}: \mathrm{MeOH}$ $(9: 1,35.00 \mathrm{mg})$ was purified by preparative TLC using the solvent system $n$-hexane: EtOAc (1:4) to give two bands. The first band with $\mathrm{R}_{\mathrm{f}} 0.38$ (brown color with $\mathrm{H}_{2} \mathrm{SO}_{4}-\mathrm{MeOH}$ ) was taken to give colorless oil (3.5 mg) of compound $\mathbf{1}$.

Sinulardiol (1): (3E, 6E)-1-isopropyl-4,8,13trimetil-15-oxa-bicyclo [10.2.1] pentadeca-3,6dien-8,14-diol; Colorless oil; IR $\lambda_{\max }$ (film) $\mathrm{cm}^{-1}$ : 3423 (O-H), 3180 (O-H), 2937 (C-H), 1645 (C=C), 1378, 1221, 1045; ${ }^{13} \mathrm{C} \mathrm{NMR}\left(\mathrm{CDCl}_{3}, 150 \mathrm{MHz}\right)$ and ${ }^{1} \mathrm{H}$ NMR $\left(\mathrm{CDCl}_{3}, 600 \mathrm{MHz}\right)$ spectroscopic data (Table 1); LCESIMS (negative mode) $\mathrm{m} / \mathrm{z}$ 321.48 [M-H] $^{-}$(Calculated $\mathrm{m} / \mathrm{z} \quad 322.48$ for $\mathrm{C}_{20} \mathrm{H}_{34} \mathrm{O}_{2}$ ).

$\Delta^{9(15)}$-africanene (2)
Colorless oil; ${ }^{13} \mathrm{C}$ NMR $\left(\mathrm{CDCl}_{3}, 150 \mathrm{MHz}\right)$ and ${ }^{1} \mathrm{H}$ $\mathrm{NMR}\left(\mathrm{CDCl}_{3}, 600 \mathrm{MHz}\right)$ spectroscopic data (Table 1)

10(14)-aromadendrene (3)

Colorless oil, ${ }^{1} \mathrm{H}$ NMR $\left(\mathrm{CDCl}_{3}, 600 \mathrm{MHz}\right): \delta=$ $2.66(1 \mathrm{H}, \mathrm{m}, \mathrm{H}-1), 1.86\left(1 \mathrm{H}, \mathrm{m}, \mathrm{H}_{\mathrm{a}}-2\right), 1.70$ $\left(\mathrm{H}, \mathrm{m}, \mathrm{H}_{\mathrm{b}}-2\right), 1.75\left(1 \mathrm{H}, \mathrm{m}, \mathrm{H}_{\mathrm{a}}-3\right), 1.32(\mathrm{H}, \mathrm{m}$, $\left.\mathrm{H}_{\mathrm{b}}-3\right), 1.88$ (1H, m, H-4), 2.07 (1H, m, H-5), $0.25(1 \mathrm{H}, \mathrm{dd}, J=10.2,9.0 \mathrm{~Hz}, \mathrm{H}-6), 0.55(1 \mathrm{H}$, ddd, $J=10.8,9.0,6.0 \mathrm{~Hz}, \mathrm{H}-7), 1.82$ (1H, m, $\left.\mathrm{H}_{\mathrm{a}}-8\right), 1.22\left(1 \mathrm{H}, \mathrm{m}, \mathrm{H}_{\mathrm{b}}-8\right), 2.30\left(2 \mathrm{H}, \mathrm{m}, \mathrm{H}_{2}-9\right)$, 0.96 (3H, s, H3-12), 1.00 (3H, s, H3-13), 4.70 $\left(1 \mathrm{H}, \mathrm{dd}, J=2.4,1.8 \mathrm{~Hz}, \mathrm{H}_{\mathrm{a}}-14\right), 4.73(1 \mathrm{H}, \mathrm{ddd}$, $\left.J=2.4,1.8,1.2 \mathrm{~Hz}, \mathrm{H}_{\mathrm{b}}-14\right), 0.94$ (3H, d, $J=7.2$ $\left.\mathrm{Hz}, \mathrm{H}_{3}-15\right) ;{ }^{13} \mathrm{C} \mathrm{NMR}\left(\mathrm{CDCl}_{3}, 150 \mathrm{MHz}\right): \delta=$ 152.6 (C, C-10), $109.7\left(\mathrm{CH}_{2}, \mathrm{C}-14\right), 50.8(\mathrm{CH}$, C-1), 42.2 (CH, C-4), 37.8 (CH, C-5), 35.7 $\left(\mathrm{CH}_{2}, \mathrm{C}-9\right), 31.2\left(\mathrm{CH}_{2}, \mathrm{C}-3\right), 28.6\left(\mathrm{CH}_{3}, \mathrm{C}-\right.$ 13), $28.2(\mathrm{CH}, \mathrm{C}-2), 24.8(\mathrm{CH}, \mathrm{C}-7), 23.5$ (CH, C-6), 22.3 (C, C-8), 17.2 (C, C-11), 16.4 $\left(\mathrm{CH}_{3}, \mathrm{C}-15\right), 15.9\left(\mathrm{CH}_{3}, \mathrm{C}-14\right)$.

Palustrol (4)

Colorless oil, ${ }^{1} \mathrm{H}$ NMR $\left(\mathrm{CDCl}_{3}, 600 \mathrm{MHz}\right): \delta=$ $1.84\left(1 \mathrm{H}, \mathrm{m}, \mathrm{H}_{\mathrm{a}}-2\right), 1.37\left(1 \mathrm{H}, \mathrm{m}, \mathrm{H}_{\mathrm{b}}-2\right), 1.82$ $\left(2 \mathrm{H}, \mathrm{m}, \mathrm{H}_{2}-3\right), 2.15(1 \mathrm{H}, \mathrm{m}, \mathrm{H}-4), 1.60(1 \mathrm{H}$, $\mathrm{dd}, J=10.2,10.2 \mathrm{~Hz}, \mathrm{H}-5), 0.51(1 \mathrm{H}, \mathrm{dd}, J=$ $10.8,9 \mathrm{~Hz}, \mathrm{H}-6), 0.68$ (1H, ddd, $J=10.8,9,6.6$ $\mathrm{Hz}, \mathrm{H}-7), 1.88\left(1 \mathrm{H}, \mathrm{m}, \mathrm{H}_{\mathrm{a}}-8\right), 1.06\left(1 \mathrm{H}, \mathrm{m}, \mathrm{H}_{\mathrm{b}}-\right.$ 8), $1.47\left(1 \mathrm{H}, \mathrm{m}, \mathrm{H}_{\mathrm{a}}-9\right), 1.35\left(1 \mathrm{H}, \mathrm{m}, \mathrm{H}_{\mathrm{b}}-9\right)$, 1.27 (1H, m, H-10), $1.03\left(3 \mathrm{H}, \mathrm{s}, \mathrm{H}_{3}-12\right), 1.06$ $\left(3 \mathrm{H}, \mathrm{s}, \mathrm{H}_{3}-13\right), 0.98\left(3 \mathrm{H}, \mathrm{d}, J=6.6 \mathrm{~Hz}, \mathrm{H}_{3}-14\right)$, $0.92\left(3 \mathrm{H}, \mathrm{d}, J=6.6 \mathrm{~Hz}, \mathrm{H}_{3}-15\right) ;{ }^{13} \mathrm{C} \mathrm{NMR}$ $\left(\mathrm{CDCl}_{3}, 150 \mathrm{MHz}\right): \delta=85.7(\mathrm{CH}, \mathrm{C}-1), 47.2$ (CH, C-5), 46.1 (CH, C-10), $38.9\left(\mathrm{CH}_{2}, \mathrm{C}-2\right)$, 35.0 (CH, C-4), $32.8\left(\mathrm{CH}_{2}, \mathrm{C}-3\right), 32.3\left(\mathrm{CH}_{2}\right.$, C-9), $28.9\left(\mathrm{CH}_{3}, \mathrm{C}-13\right), 27.1(\mathrm{CH}, \mathrm{C}-7), 24.5$ $\left(\mathrm{CH}_{2}, \mathrm{C}-8\right), 22.0$ (CH, C-6), 19.9 (C, C-11), 
determination of the inhibition of the Ehrlich ascites tumor was made in case of africanene (Reddy et al., 1999).

In the course of our continued program in investigation of the Red sea organisms screening for bioactive compounds, a specimen of the common soft coral along Jeddah's coast, Sinularia polydactyla was selected. The known cembranoid diterpene alcohol sarcotrocheldiol A (1), in addition to three known sesquiterpenoids, $\Delta^{9(15)}-$ africanene (2), 10(14)-aromadendrene (3) and palustrol (4), which were identified by comparison of their spectral data with those in literature (Kashman et al., 1980; Warmers and König, 1999; Cheer et al., 1976) (Figure 1). The antimicrobial activity of the previous metabolites was also evaluated.

\section{Materials and Methods}

\section{General}

Chromatographic material: Silica gel 60 for column chromatography (60-120 mesh LR), for thin layer chromatography TLC aluminum sheets $20 \times 20 \mathrm{~cm}$ Silica gel $60 \mathrm{~F}_{254}$ was used; for preparative, Pre-coated TLC glass plates SIL G-25 UV 254, $0.25 \mathrm{~mm}$ silica gel were used. Optical rotations were measured by ATAGO POLAX-L 2 polarimeter. Nuclear Magnetic Resonance spectra were recorded for 1D- and 2D-NMR: Bruker AVANCE III WM at $600 \mathrm{MHz}$ and ${ }^{13} \mathrm{C}-\mathrm{NMR}$ at $150 \mathrm{MHz}$ spectrometer. Chemical shifts are given in $\delta$ (ppm) relative to TMS as internal standard. Electron impact mass spectra were determined at $70 \mathrm{eV}$ on a Kratos GCMS-25 instrument.

The spray reagent is methanol- sulfuric acid. A freshly prepared solution was made by adding concentrated sulfuric acid $50 \mathrm{ml}$ to methanol $50 \mathrm{ml}$.
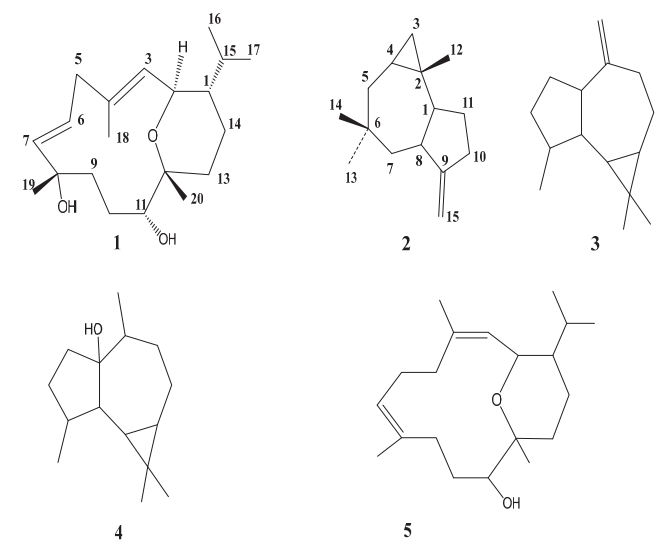

Figure 1. Compounds isolated from Sinularia polydactyla

The soft coral Sinularia polydactyla was collected in Dec. 2016, off the Saudi Arabia Red Sea Coast at Jeddah. Voucher sample (JAD 09080) was deposited at the Chemistry Department, Faculty of Science, King Abdulaziz University, Jeddah, Saudi Arabia.

\section{Extraction and Isolation}

Coral material was washed with water and dried in the shade at room temperature. The dried material $(80.00 \mathrm{~g})$ was exhaustively extracted with equal volumes of $\mathrm{CHCl}_{3} / \mathrm{MeOH}$ ( $2 \times 6 \mathrm{~L}, 24$ hours for each batch) at room temperature. The residue $(20.25 \mathrm{~g})$ was partitioned between $\mathrm{CH}_{2} \mathrm{Cl}_{2}$ and water, the organic layer was dried ( $8 \mathrm{~g}$ ) chromatographed on NP (Merck, 60G) column chromatography employing $n$-hexane/ethyl acetate mixtures with increasing polarity. Fractions of $\sim 50 \mathrm{ml}$ were collected. TLC was carried out by employing silica-gel chromatoplates, using the appropriate solvent system and 50\%-sulfuric acid in methanol as spraying reagent. Fractions containing a single compound were combined 


\title{
Bioactive metabolites from the Red Sea soft coral Sinularia polydactyla
}

\author{
Mohamed A. Ghandourah \\ Department of Marine Chemistry, Faculty of Marine Sciences, King Abdulaziz University, \\ PO. Box 80207, Jeddah 21589, Saudi Arabia.
}

\begin{abstract}
A cembranoid diterpene alcohol (1), along with the africane-type squiterpene $\Delta^{9(15)}$-africanene (2), and two aromadendrane-type sesquiterpenoids; 10(14)-aromadendrene (3) and palustrol (4) have been isolated from the organic extract of the soft coral Sinularia polydactyla. Chemical structures were established on the basis of NMR, MS, IR spectroscopic analysis and comparison with literature. The antibacterial activity of all isolated compounds was evaluated.
\end{abstract}

Keywords: Red Sea, octacorallia, diterpenes, sesquiterpenes, antimicribial

\section{Introduction}

Soft bodied corals are a group of colonial invertebrates [phylum Coelentrata (cnidaria), class Anthozoa, subclass octacorallia, orders Alcyonaceae] (Barnes, 1968). Members of the genus Sinularia are widely distributed in the tropical reef environment. Out of one hundred identified species of the genus Sinularia, only fourteen have been investigated for secondary metabolite contents (Blunt et al., 2003; Faulkner, 1986). Literature screening revealed the richness of the Sinularia species with natural products, such as, seco- and polyhydroxylated sterols, sesquiterpenoids, diterpenoids, and nitrogen containing compounds (Chen et al., 2015; Lei et al., 2014; Lakshmi and Kumar, 2009).

The Sinularia isolated metabolites were shown to possess an appreciated spectrum of biological activities, including cytotoxic, antifouling, antimicrobial, anti-inflammatory, histamine-release and inhibition activities (Lakshmi and Kumar, 2009). The genus
Sinularia is a prolific source of biologically active diterpenoids, especially those with cembrane carbon skeleton. Cembranoids are a 14-membered carbocyclic skeleton, festooned with carbon-carbon double bond(s) and methyl groups. This framework is easily exposed to oxidation, photochemical, rearrangement and enzymatic processes leading to the formation of cyclic ether, lactone, pyran, or furan moieties around the cembrane skeleton (Abdel-Lateff et al., 2014). Next to diterpenoids, sesquiterpenes come as second common terpenoids especially those with africane-typese squiterpenoid, as major secondary metabolites from the genus Sinularia. The sesquiterpenoid, africanene (2) was tested for short term in vitro cytotoxic activity against the Ehrlich ascites carcinoma (EAC) and Dalton's lymphoma ascites (DLAT) tumor cells at $10 \mathrm{mg} \mathrm{mL}^{-1}$ concentration, which caused the death of the EAC and DLAT cells to $100 \%$ and $92 \%$, respectively. While in in vivo cytotoxic assay, 